\title{
US space agency escapes the worst of cuts
}

Washington. In the midst of gridlock and government shutdown, the US Senate and House of Representatives quietly settled their differences last week over funding levels for three key science agencies: the National Aeronautics and Space Administration (NASA), the National Science Foundation (NSF) and the Environmental Protection Agency (EPA).

NASA's Mission to Planet Earth, a major programme of climate and environmental monitoring, emerged as the least unscathed, with a cut of only $\$ 81$ million to the Clinton administration's original request of $\$ 1.34$ billion - $\$ 20$ million less than the Senate had approved, but $\$ 257$ million more than the House had granted.

The NASA vote was a defeat for House Republicans, particularly Robert Walker (Republican, Pennsylvania), chair of the House Science Committee, who had sought deep cuts in NASA's Earth Observing System (EOS) of satellites. In contrast, it was a victory for Senator Barbara Mikulski (Democrat, Maryland), whose state is home to the Goddard Space Flight Center, where much of the EOS work will be carried out.

In preserving NASA's Earth science programme, the conference members may have been influenced by a recent National Research Council study that argued strongly against cutting near-term EOS funding, while suggesting that future savings could come from redesigning a proposed system for distributing data to scientists (see Nature 377, 191; 1995).

Other threatened NASA projects also fared well in the conference. The proposed Space Infrared Telescope Facility (SIRTF), for example, lost only $\$ 5$ million of a \$15-million request, rather than being eliminated as the House had proposed. That

\section{$\mathrm{NIH}$ discovers who counts as 'essential'}

Washington. Last week's unprecedented six-day shutdown of the US government halted the work of most grant-giving agencies, and sent home thousands of scientists and support staff at government laboratories.

At the main campus of the National Institutes of Health (NIH) at Bethesda, Maryland, only those scientists, administrators and other employees considered 'essential' were permitted to work - numbering about 2,000 of the $16,000 \mathrm{NIH}$ staff. The library was closed, seminars were cancelled, telephones were left unanswered, and the ordering of supplies was at a standstill.

Most centres of the National Aeronautical and Space Agency (NASA) were also closed (see above) and all but 22 of the National Science Foundation's 1,300 staff were sent home. But the Department of Energy's laboratory network worked as normal, as the department is one of a handful for which a budget had been agreed.

"We have just about run out of [the radioactive isotope] P-32," said Robert Nussbaum, chief of the laboratory of genetic disease research at NIH. "This is not fun. [Our research is] being seriously interfered with." Nussbaum and others said they would have had to wind down experiments if the shutdown had continued for longer than two weeks.

The closure, however, ended on Monday, after the Clinton administration and Congress agreed to a temporary spending measure that will fund programmes until 13 December. Under a complex formula, the measure will fund $\mathrm{NIH}$ at its
1995 level until then, and most other agencies at the lower level proposed by the Senate or the House.

NIH laboratories working with cell lines, animals and patients were allowed sufficient personnel to avoid any damage or harm. But the definition of 'essential' workers was interpreted differently by individual laboratories resulting in widespread resentment among some of those laid off. NIH stuck to its hierarchical structure in making lay-offs: laboratory heads were asked to choose who would stay and who would go. Final decisions were made by the intramural programme office.

"It was a psychological blow to those considered non-essential," says Vincent Hearing, a biochemist with 25 years experience at the National Cancer Institute. Most laboratory chiefs appear to have been deemed essential, and were at work last week. But Clinton and Congress agreed that those who were sent home will still be paid. A spokesperson for the NSF - speaking from home - said that Neal Lane, the NSF director, decided to lay off everyone except himself, his deputy and security staff, in order to minimize "morale problems" if some staff were considered 'essential' and others not.

James Sheirer, deputy director of the division of extramural affairs at $\mathrm{NIH}$, confirmed that his office, responsible for administering grants, was "at a dead stop". NIH awards to be made on 1 December may be delayed, as will most other grant-related business.

Adrianne Appel \& Colin Macilwain should allow the project to continue plans for a launch in 2002.

Legislators participating in the funding 'conference' neatly split the \$40-million difference between proposed House and Senate funding levels for the NSF, setting the final mark at $\$ 3.18$ billion. Under the compromise plan, the 'research and related activities' account, which supports most NSF grants, increases slightly over 1995 levels.

EPA fared better in the compromise budget than it had in either chamber. The conference allocated $\$ 5.7$ billion for the environmental agency, an increase of $\$ 48$ million over the Senate mark and $\$ 817$ million over the House allocation. That still may not be enough, however, to prevent a veto by President Bill Clinton. He wants more money both for EPA and for seeking successors. his proposed pro-

gramme of national service, which, along with federal housing programmes, is funded by the same bill.

Arguments about the legislation were expected to continue at least into this week. But negotiations from now on are unlikely to involve NSF and NASA, so the levels set for them last week are likely to stand.

Meanwhile, workers at those two agencies and EPA who had been temporarily laid off returned to work this week after Clinton and Congressional Republicans came to an agreement over the weekend on general principles for balancing the federal budget. A new continuing resolution provides temporary funding (see left) until midDecember, or until the appropriations bill is passed.

During the four-day government shutdown, some scientists managed to get into their offices to keep up with workloads. But most could not, and telephones at all three agencies rang unanswered. Not all of NASA's civil servants were laid off. For example, personnel at Ames Research Center responsible for monitoring the Galileo probe, which arrives at Jupiter on 7 December, were among those considered 'essential' and allowed to report for work. But a Galileo pre-arrival press conference and an educational session for 300 teachers were both cancelled.

Even senior NASA officials felt the effects of the shutdown. When Daniel Goldin, the agency's administrator, wanted to make a congratulatory call to shuttle astronauts meeting their Russian counterparts in orbit, he found his headquarters office closed. He ended up telephoning from his living room.

Tony Reichhardt 